Nigerian Journal of Physiological Sciences 24 (1): $17-23$ @Physiological Society of Nigeria, 2009

Available online/abstracted at http://www.bioline.org.br/np; www.ajol.info/journals.njps; www.cas.org

\title{
THE EFFECT OF THE AQUEOUS EXTRACT OF KOHAUTIA GRANDIFLORA ON PARACETAMOL INDUCED LIVER DAMAGE IN ALBINO RATS
}

\author{
S. H. GARBA ${ }^{1}$, N. SAMBO ${ }^{2}$ AND U. BALA ${ }^{1}$ \\ Department of Human Anatomy ${ }^{1}$, Department of Human Physiology ${ }^{2}$, College of Medical Sciences, University of \\ Maiduguri, Maiduguri, Nigeria. E-Mail: saniwakawa@yahoo.co.uk Tel: 234 (0) 8054807002
}

\begin{abstract}
Summary: This study was carried out to investigate the hepatoprotective effect of the aqueous extract of Kohautia grandiflora on paracetamol induced hepatotoxicity in rats. A total of 20 albino rats of the Wister strain weighing 120-180g were used for the study. The animals were divided into 4 groups of 5-rats each (I-IV). Groups I, II and III served as the normal, paracetamol and plant extract controls and were administered with normal saline, $500 \mathrm{mgkg}^{-1}$ of paracetamol and $300 \mathrm{mg} / \mathrm{kg}$ of the plant extract respectively for 7 days while rats in group IV served as the treatment group and were pre-treated with $300 \mathrm{mg} / \mathrm{kg}$ of the plant extract respectively for 7 days before $500 \mathrm{mg} / \mathrm{kg}$ of paracetamol was administered on the $8^{\text {th }}$ day. At the end of the experimental period, blood was obtained from each rat for the determination of serum levels of aspartate transaminase (AST), alanine transaminase (ALT), alkaline phosphatase (ALP), albumin and bilirubin. Biochemical analysis of the serum obtained showed a significant increase $(\mathrm{P}<0.05)$ in the levels of AST, ALT, ALP and Albumin in rats administered with 500mg/kg of paracetamol and $300 \mathrm{mg} / \mathrm{kg}$ of the extract respectively. Pre-treatment of the animals with the extract caused a decrease in the levels of these enzymes. Histopathological assessments of the liver sections of rats administered with $500 \mathrm{mg} / \mathrm{kg}$ of paracetamol and $300 \mathrm{mg} / \mathrm{kg}$ of the extract showed congestion of the venous sinusoids, necrosis, edema, mononuclear infiltration and cloudy swellings with the severity higher in the paracetamol treated group. Pre-treatment with $300 \mathrm{mg} / \mathrm{kg}$ of the extract revealed a slight hepatoprotection compared with the rats that were administered with paracetamol alone. This study has shown that the aqueous extract of Kohautia grandiflora possesses slight hepatoprotective property.
\end{abstract}

Key words: Kohautia grandiflora, paracetamol, liver enzymes, hepatotoxicity

\section{Introduction}

The liver is sometimes referred to as the "great chemical factory" of the body, because the body depends on the liver to regulate, synthesize, store and secrete many important proteins, nutrients, chemical and to purify and clear toxin or unneeded substance from the body. Most importantly, the liver is considered to be the center of metabolic transformation of drugs and other toxins entering from the gastrointestinal tract as such the normal or healthy functioning of the liver determines the health status of an individual. For this reason, a lot of research on medicinal plants and other chemical substances with hepatotoxic or hepatoprotective properties have been well documented. It has been reported that about 160 phyto-constituents from 101 plants have hepatoprotective activity with the protective herbal drugs containing a variety of chemical constituents like phenols, coumarins, lignans, essential oil, monoterpenes, carotinoids, glycosides, flavanoids, organic acids, lipids, alkaloids and xanthines. Plant extracts of many crude drugs from about 25 plants are today used for the treatment of liver disorders. In spite of tremendous strides in modern medicine, there are hardly any drugs that stimulate liver function, offer protection to the liver from damage or help regeneration of hepatic cell (Chaterjee, 2000). There are however, numbers of drugs employed in traditional system of medicine for liver afflictions (Chattopadhyay, 2003). Many formulations containing herbal extracts are sold in the Indian market for liver disorders. But management of liver disorders by a simple and precise herbal drug is still an intriguing problem. Several Indian medicinal plants have been extensively used in the Indian traditional system of medicine for the management of liver disorder. Some of these plants have already been reported to poses strong antioxidant activity (Achuthan et al., 2003, Aniya et al., 2002 and Gupta et al., 2006).

The hepatoprotective effect of Epaltes divericata against carbon tetrachloride-induced hepatotoxicity in mice have demonstrated a significant reduction in 
the serum levels of Alanine transaminase (ALT), Aspartate transaminase (AST) and Alkaline phosphatase (ALP) that were pre-treated with the plant extract and a significant increase in the liver reduced glutathione level 24hrs after the administration of $\mathrm{CCl}_{4}$ and in paracetamol induced hepatoxicity. Solanum trilobatum has also shown hepatoprotection against $\mathrm{CCl}_{4}$ hepatic damage in albino rats. Akintonwa and Essien (1990) have also demonstrated the hepatoprotective effect of Garcinia kola seed extract against paracetamol-induced hepatotoxicity in rats. Various workers have reported the hepatoprotective effects of plants and their products such as the alcoholic extract of Andrographic paniculata, Terminalis beleria, Picrorhiza kuroa, Gymnosporia Montana, Picerthiza Kurroale, Ricinus Communis and Ficus sycomorus (Garba et al., 2007). Kolaviron has been reported to significantly prevent hepatotoxicity induced by several hepatotoxic agents such as phalloidin, thioacetamide and paracetamol (Iwu et al., 1987, Akintonwa and Essein, 1990; Garba et al, 2007).

Paracetamol (acetaminophen) is a widely used anti-pyretic /analgesic and produces acute liver damage if overdoses are consumed and is mainly metabolized in liver to excretable glucuronide and sulphate conjugates (Jollow et al, 1974, Wong et al, 1981). However, the hepatotoxicity of paracetamol has been attributed to the formation of toxic metabolites when a part of paracetamol is activated by hepatic cytochrome P-450 ( Savides and Oehme, 1983), to a highly reactive metabolite N-acetyl-Pbenzoquinoneimine (NAPQI) (Vermeulen et al, 1992). NAPQI is initially detoxified by conjugation with reduced glutathione (GSH) to form mercapturic acid (Moore et al, 1985). However, when the rate of NAPQI formation exceeds the rate of detoxification by GSH, it oxidizes tissue macromolecules such as lipid or -SH group of protein and alters the homeostasis of calcium after depleting GSH. Paracetamol, an analgesic and antipyretic, is assumed to be safe in recommended doses; overdoses, however, produce hepatic necrosis. Small doses are eliminated by conjugation followed by excretion, but when the conjugation enzymes are saturated, the drug is diverted to an alternative metabolic pathway, resulting in the formation of a hydroxylamine derivative by cytochrome $\mathrm{P} 450$ enzyme. The hydroxylamine derivative, a reactive electrophillic agent, reacts non-enzymatically with glutathione and detoxifies. When the hepatic reserves of glutathione depletes, the hydroxylamine reacts with macromolecules and disrupts their structure and function. Extensive liver damage by paracetamol itself decreases its rate of metabolism and other substrates for hepatic microsomal enzymes. Induction of cytochrome $\mathrm{P} 450$ or depletion of hepatic glutathione is a prerequisite for paracetamol-induced toxicity.

Kahautia grandiflora popularly known as "Rimin samari" or "Rimin sauri" in Hausa is a reputed medicinal plant used in the traditional system of medicine in the northern part of Nigeria and forms the major ingredient of several traditional medicinal preparations useful in the treatment of gastric problems, inflammation, respiratory tract infections and remedies for conjugal affection. Despite its numerous medicinal uses and importance in the treatment of many illness and diseases in Nigeria no scientific and methodical investigation has so far been reported in literature regarding its action on liver. Therefore, the present investigation was designed to study the possible protective potentials of the aqueous extract of Kohautia grandiflora against paracetamol induced hepatotoxicity in albino rats.

\section{Materials and methods}

Collection and identification of plant materials

The fresh plant (whole plant) of Kohautia grandiflora was purchased from local herbalist located within the Monday market in Maiduguri Metropolis. The plant was identified and authenticated by Dr. S.S. Sanusi (Plant Taxonomist) of the Department of Biological Sciences, University of Maiduguri, Borno state. The plant was shade-dried for 5 days and pulverized using a pestle and mortar. The pulverized part was stored in cellophane bags at room temperature.

\section{Preparation of extract}

The World Health Organization (WHO, 1992) procedure of extraction was adopted for this study. A total of one hundred grams of the powder of Kohautia grandiflora were subjected to exhaustive soxhlet extraction in $500 \mathrm{~mL}$ of distilled water for $72 \mathrm{hrs}$. The extract obtained was concentrated in a water bath until a constant dark sticky residue was obtained, this was further oven dried and maintained in a dessicator until a constant weight was obtained. The dried extract obtained was stored in a tightly stoppered container in a refrigerator at $-4^{\circ} \mathrm{C}$ until required. Stock solution of the extract was prepared by dissolving $5 \mathrm{~g}$ weight of the powdered extract in 50 $\mathrm{mL}$ of normal saline and the concentration used was $0.1 \mathrm{~g} \mathrm{~mL}^{-1}$

\section{Animals}

This study was carried out in the Departments of Human Anatomy and Human Physiology research laboratory, University of Maiduguri, Nigeria between March and October 2007. A total of 25 adult albino rats of the Wister strain weighing between 120 and 
$180 \mathrm{~g}$ were used for both the acute and hepatoprotective studies. The rats were purchased from the animal house of the Department of Pharmacology and Pharmaceutical Sciences, University of Jos, Plateau State, Nigeria. Following an acclimatization period of 2 weeks, the rats were individually identified by color tattoo and weighed. The rats were kept in plastic cages under standard laboratory conditions at room temperature with $12 \mathrm{hrs}$ light/dark cycle with access to standard laboratory diet (Sanders Nigeria Limited, Kaduna) and drinking water ad libitum.

\section{Acute toxicity study}

This study was conducted according to the Organisation for Economic Cooperation and Development (OECD) revised up and down procedure for acute toxicity testing (OECD, 2001). A limit dose of $2000 \mathrm{mgkg}^{-1}$ of the aqueous extract of Kohautia grandiflofa was used for this study. The limit dose was performed using 5 healthy adult nulliparous female rats. The rats were fasted overnight from food but not water prior to dosing and then weighed before the extract was administered in a single dose by gavage. The limit dose of $2000 \mathrm{mg} / \mathrm{kg}$ of the aqueous extract was given to the first rat orally and the rat was observed for mortality and clinical signs for the first hour, then hourly for three hours and then periodically for 72 hours. Other rats were subsequently dosed sequentially at 48 hours interval. The $\mathrm{LD}_{50}$ was predicted to be above $2000 \mathrm{mgkg}^{-1}$ if three or more rats survived.

\section{Hepatoprotective study:}

The aqueous extract of Kohautia grandiflora was orally administered daily in graduated doses. A total of 20 rats were used in this study, they were weighed and randomly divided into four groups of 5 rats each (I-IV). Group I served as normal control and were administered normal saline equivalent to the volume administered to the highest dosed experimental rats. Group II served as the paracetamol control group and were administered $500 \mathrm{mg} / \mathrm{kg}$ body weight paracetamol for $48 \mathrm{hrs}$ to induce hepatic damage. Group III served as the extract control group and were administered with $300 \mathrm{mgkg}^{-1}$ of the plant extract for seven days to observe for related toxicity of the plant on the liver. Rats in group IV were pre-treated with $300 \mathrm{mgkg}^{-1}$ of the plant extract for 7 days before $500 \mathrm{mgkg}^{-1}$ of paracetamol was administered on the $8^{\text {th }}$ day and observed for 24hrs. At the end of the experimental period, body weights of all rats were recorded. The rats were then sacrificed and the blood obtained was subjected to biochemical investigation. The liver was then harvested, trimmed of any adherent tissue, the wet weight taken and preserved in $10 \%$ formaldehyde solution for subsequent histopathological examination.

\section{Biochemical analysis:}

Blood collected from the animals by transection of the jugular vein were put into sterile bottles and centrifuged at a rate of 12,000 revolutions per minute (rpm) for $10 \mathrm{~min}$. The clear serum obtained was analyzed for Aspartate transaminase (AST), Alanine transaminase (ALT), Alkaline phosphatase (ALP), Albumin and Bilirubin using Randox Laboratory kits at the Department of Chemical Pathology, University of Maiduguri Teaching Hospital Maiduguri (UMTH).

\section{Histological analysis}

The liver tissue obtained was carefully weighed, fixed in $10 \%$ formaldehyde solution, embedded in paraffin wax and sectioned at $5 \mu \mathrm{m}$. Sections were stained with Haematoxylin and Eosin and mounted in Canada balsam. Light microscopic examination of the sections was then carried out and micrographs produced using Vanox-T Olympus photographing microscope.

\section{Statistical analysis}

Numerical data obtained from this study were expressed as the mean value \pm standard error of mean. Differences among the control and treatment groups were determined using statistical package (GraphPad Instat). A probability level of less than $5 \%(\mathrm{p}<0.05)$ was considered significant.

\section{Results}

Acute Toxicity

None of the 5 rats died or showed any sign of toxicity at the limit dose of $2000 \mathrm{mg} / \mathrm{kg} / \mathrm{oral}$ in the first 48 hours and no evidence of toxicity was noted during the period of observation. The $\mathrm{LD}_{50}$ in rats was therefore taken as above $2000 \mathrm{mg} / \mathrm{kg} /$ oral.

Effect of the aqueous extract on mean organ and body weights:

The extract had no significant effect on the body weight of the rats but rats pre-treated with $300 \mathrm{mgkg}^{-1}$ of the extract and those administered $500 \mathrm{mgkg}^{-1}$ of paracetamol showed significant loss in body weight (Table 1). 
Table 1: Effect of pretreatment with the aqueous root extract of Kohautia grandiflora against paracetamol induced hepatotoxicity on mean liver and body weights

\begin{tabular}{|c|c|c|c|c|c|c|}
\hline \multirow[t]{2}{*}{ Groups } & \multicolumn{2}{|c|}{$\begin{array}{c}\text { Doses administered } \\
\left(\mathrm{mgkg}^{-1}\right)\end{array}$} & \multirow{2}{*}{$\begin{array}{c}\text { Initial body } \\
\text { weight } \\
(\mathrm{gm})\end{array}$} & \multirow{2}{*}{$\begin{array}{c}\text { Final body } \\
\text { weight } \\
(\mathrm{gm})\end{array}$} & \multirow{2}{*}{$\begin{array}{c}\text { Body weight } \\
\text { difference } \\
(\mathrm{gm})\end{array}$} & \multirow{2}{*}{$\begin{array}{c}\% \\
\text { Weight } \\
\text { change }\end{array}$} \\
\hline & Extract & Paracetamol & & & & \\
\hline I & 0 & 0 & $140.92 \pm 4.93$ & $156.22 \pm 5.62$ & $150.30 \pm 1.05$ & $9.78 \pm 0.48$ \\
\hline II & 0 & 500 & $140.58 \pm 6.40$ & $154.08 \pm 6.32$ & $13.04 \pm 1.64$ & $8.53 \pm 1.03$ \\
\hline II & 300 & 0 & $145.90 \pm 6.62$ & $159.82 \pm 6.37$ & $14.52 \pm 2.73$ & $9.12 \pm 1.81$ \\
\hline VI & 300 & 500 & $144.00 \pm 6.69$ & $150.38 \pm 7.18$ & $6.38 \pm 0.57$ & $4.22 \pm 0.23$ \\
\hline
\end{tabular}

Results are presented as Means \pm SEM. $\quad \mathrm{N}=5$

Table 2: Effect of pretreatment with the aqueous extract of Kohautia grandiflora against paracetamol inducedhepatotoxicity on biochemical parameters

\begin{tabular}{|c|c|c|c|c|c|c|c|}
\hline Groups & \multicolumn{2}{|c|}{$\begin{array}{c}\text { Doses administered } \\
\left(\mathrm{mgkg}^{-1}\right)\end{array}$} & $\begin{array}{c}\text { AST } \\
\left(I U L^{-1}\right)\end{array}$ & $\begin{array}{c}\text { ALT } \\
\left(I U L^{-1}\right)\end{array}$ & $\begin{array}{c}\text { ALP } \\
\left(I U L^{-1}\right)\end{array}$ & $\begin{array}{c}\text { T/P } \\
\left(g L^{-1}\right)\end{array}$ & $\begin{array}{c}A L B \\
\left(g L^{-1}\right)\end{array}$ \\
\cline { 2 - 7 } & Extract & Paracetamol & & & & & \\
\hline I & 0 & 0 & $38.23 \pm 0.15$ & $34.11 \pm 3.11$ & $132.18 \pm 1.12$ & $53.15 \pm 2.11$ & $30.42 \pm 0.17$ \\
\hline II & 0 & 500 & $68.34 \pm 2.45$ & $88.34 \pm 4.13$ & $162.26 \pm 3.20$ & $88.15 \pm 4.17$ & $51.54 \pm 0.22$ \\
\hline III & 300 & 0 & $48.10 \pm 1.15$ & $63.12 \pm 2.14$ & $142.21 \pm 1.10$ & $68.11 \pm 3.16$ & $41.00 \pm 0.19$ \\
\hline IV & 450 & 500 & $68.34 \pm 2.45^{* * *}$ & $88.34 \pm 4.13^{* * *}$ & $162.26 \pm 3.20$ & $88.15 \pm 4.17$ & $51.54 \pm 0.22$ \\
\hline
\end{tabular}

Effect of the aqueous extract on biochemical parameters:

The effects of the administration of the aqueous extract of Kohautia grandiflora and paracetamol on biochemical parameters are presented in Table 2. Biochemical analysis of blood serum showed a significant increase $(\mathrm{P}<0.05)$ in the levels of AST, ALT and ALP, there was also an increase in the levels of Total protein and Albumin though not statistically significant.

\section{Histological findings}

Liver section of the control group showed normal liver parenchyma with the central vein clearly seen along with the bile ducts and hepatic arteries. The hepatocytes were neatly arranged in anastomosing plates with the sinusoids radiating from the central vein (Fig. 1).Venous congestion, necrosis and mononuclear infiltration were the histopathological changes observed in the liver of rats administered with $500 \mathrm{mgkg}^{-1}$ of paracetamol (Fig.2). Necrosis, mononuclear cell infiltration and edema were the changes observed in rats administered with $300 \mathrm{mgkg}^{-1}$ of the extract (Fig.3). Histopathological examination of the liver tissue of rats pre-treated with $300 \mathrm{mgkg}^{-1}$ of the aqueous extract showed a slight degree of protection when compared with the group administered with only $500 \mathrm{mgkg}^{-1}$ of paracetamol though there was congestion and mononuclear cell infiltration but at a lesser degree compared the paracetamol treated group (Fig.4).

\section{Discussion}

The acute toxicity value of greater than $2000 \mathrm{mg} / \mathrm{kg}$ obtain after the administration of the aqueous root extract of Kohautia grandiflora in rats is an indication of the plants none or low toxicity because an $\mathrm{LD}_{50}$ of $>$ $2000 \mathrm{mg} / \mathrm{kg}$ is classified as practically non toxic ( U.S.EPA, 2006) . The decrease in the body weight of the rats administered with the extract and paracetamol may be due to the loss of appetite observed in the cause of study, it may also arise from intestinal damage arising from the toxic effect of the plant which may have lead to decrease in food intake (Rabo, 1998). 


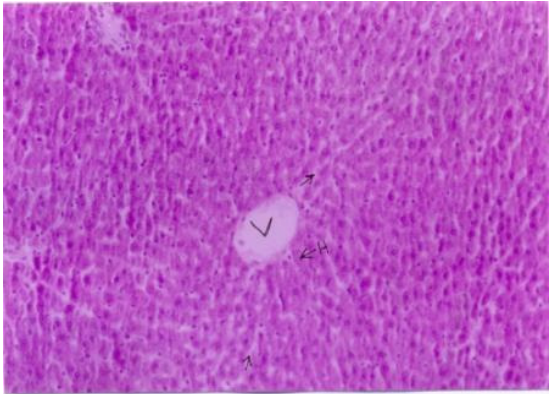

Fig 1: Micrograph of the liver of a control rat showing normal arrangement of the Central vein (V), Sinusoids (arrow) and the Hepatocytes (H). H and E stain. Mg. X 200

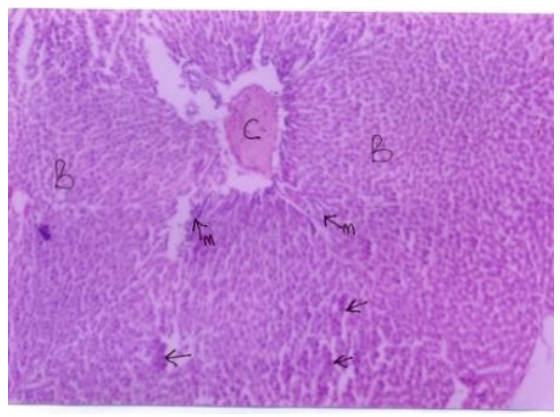

Fig 2: Micrograph of the liver of a rat administered $500 \mathrm{mgkg}^{-1}$ paracetamol showing congestion (C), necrosis (arrow) and mononuclear cell infiltration (m) .H and E stain. Mg. X 200

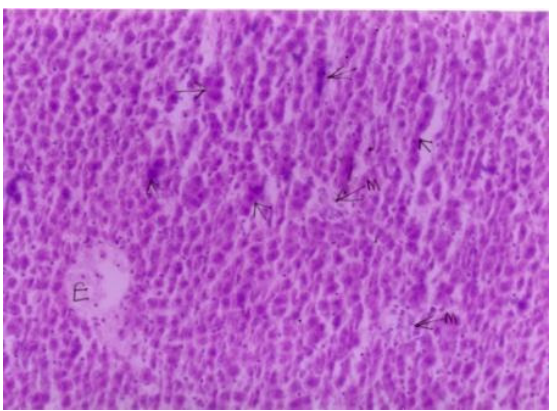

Fig 3: Micrograph of the liver of a rat administered $300 \mathrm{mgkg}^{-1}$ of the aqueous extract of Kohautia grandiflora showing necrosis (arrow), mononuclear cell infiltration $(\mathrm{m})$ and edema $(\mathrm{E})$ $\mathrm{H}$ and E stain. Mg. X 200

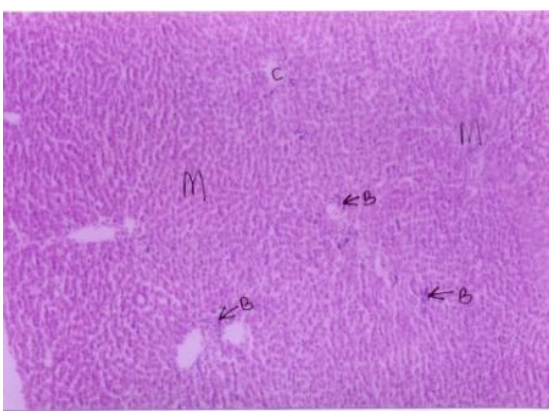

Fig 4: Micrograph of the liver of a rat pretreated with 300 $\mathrm{mgkg}^{-1}$ of the aqueous extract of Kohautia grandiflora and $500 \mathrm{mgkg}^{-1}$ of paracetamol showing mononuclear cell infiltration (B ), Congestion (C) and cloudy swelling(M). H and E stain. Mg. X 100

In the assessment of liver damage certain biomarkers of hepatotoxicity are measured and one of such biomarkers are enzyme levels such as AST and ALT because liver damage arising from necrosis or membrane damage normally releases the enzymes into circulation; therefore, measurement of these enzymes in serum gives an indication of the health status of the liver. High levels of AST indicate liver damage, as that due to viral hepatitis as well as cardiac infarction and muscle injury. ALT catalyses the conversion of alanine to pyruvate and glutamate, and is released in a similar manner. It is known that an increase in the enzymatic activity of ALT and AST in the serum directly reflects a major permeability or cell rupture, and thus ALT is more specific to the liver, and is thus a better parameter for detecting liver injury (Benjamin, 1978 and Wittwer and Bouhmwald, 1986). An increase in AST and ALT, a hepatospecific enzyme that is principally found in the cytoplasm in the rats following administration of a hepatotoxin is attributed to the increased release of enzymes from the damaged liver parenchymal cells (Benjamin,1978, Ringler and Dabich, 1979; Singh, 1980 )

Paracetamol (acetaminophen) a widely used antipyretic and analgesic drug has been known to cause hepatotoxiciy in human being and laboratory rat as such a plethora of research has been carried out to find possible protection against paracetamol-induced toxicity (Yoshinkuyi et al. 1992). Paracetamol causes acute centrilobular necrosis in rats, mice, guinea pig, hamsters, rabbits, cats, dogs and pigs (Boyd and Bereczky, 1996) and centrizonal heamorrhagic necrosis in humans mostly characcterised by 
pyknosis and eosinophilic cytoplasm (Clark ,1974 and Boyd and Bereckzky,1996).

As observed in the study, the administration of paracetamol to the treatment control group showed an increase in the levels of ALT, AST, Alkaline phosphatase and Albumin. Alkaline phosphatase levels usually increases remarkably in disease that impair bile formation and to lesser extent in hepatocellular diseases. The decrease observed in the increased levels of the enzymes AST,ALT, Alkaline phosphatase, albumin and total protein following the administration of paracetamol may be attributed to the protection offered by the administration of the aqueous extract of Kohautia grandiflora. The possible mechanism responsible for the protection of the paracetamol induced liver damage by the extract of Kohautia grandiflora may be as a result of the extract acting as a free radical scavenger by intercepting the radicals involved in paracetamol metabolism by microsomal enzymes or the extract may contain phytochemicals because a number of scientific reports indicates the role of certain flavonoids, triterpenoids and steroids in hepatoprotection against hepatotoxins. The presence of those compounds in Kohautia grandiflora may be responsible for the protective effect on paracetamol induced liver damage in rats.

In conclusion, the results of this study demonstrate that the aqueous extract of Kohautia grandiflora has hepatoprotective action against paracetamol induced hepatic damage in rats. Our results show that the hepatoprotective effects of Kohautia grandiflora may be due to its antioxidant and free radical scavenging properties. Further investigation to determine the exact phytoconstituents that is responsible for its hepatoprotective effect is recommended for further studies.

\section{Acknowledgement}

We wish to acknowledge the technical assistance of Ibrahim Wiam and Ephraim Ayuba of the Departments of Veterinary Anatomy and Human Anatomy, University of Maiduguri, Nigeria.

\section{References}

Achuthan, C. R., B. H. Babu and Padikkala, J. (2003). Antioxidant and Hepatoprotective effects of Rosa damascena. Pharmaceut. Biol. 41: 357361.

Akintonwa, A. and Essein, A. R. (1990). Protective effect of Garcinia kola Seed extract against paracetamol induced hepatotoxicity in rats. $J$. Ethnopharmacol. 29 (2): 207-211.

Aniya, Y., Miyagi, A., Nakandakari, N., Kamiya, N., Imaizumi N. and Ichiba, T. (2002). Free radical scavenging action of the medicinal herb
Limonium wrightii from the Okinawa islands. Phytomedicine. 9:239-244.

Benjamin M. N, (1978). Outline of veterinary Clinical Pathology. University press. Iowa, pp. 229-232

Boyd, E. M. and Bereckzky, G.. M. (1996). Liver damage from Paracetamol. Br. J. Pharmacol. 26: 606.

Chaterjee, T. K. (2000). Medicinal Plants with Hepatoprotective Properties. Herbal Options. Books \& Allied (P) Ltd., Calcutta, pp: 155.

Chattopadhyay, R. R. (2003). Possible mechanism of hepatoprotective activity of Azadirachta indica leaf extract: Part II. J. Ethanopharmacol. 89: 217219.

Clark, R., Thompson, R. P. H., Borirackanyavat, V., Widoop, B., Davidson, A. R., Goulding, R. and Williams, R., (1974). Hepatic damage and death from Overdose of paracetamol. Lancet, 1: 66-69.

Garba, S. H., Prasad, J. and Sandabe, U. K. (2007). Hepatoprotective effect of aqueous Root-Bark extract of Ficus sycomorus (Linn) on $\mathrm{CCl}_{4}$ induced hepatotoxicity in rats. J. Biol. Sci. 7(2): 276-281.

Gupta, A. K., Chitme, H., Dass, S. K. and Misra, N. (2006). Antioxidant activity of Chamomile recutita capitula methanolic extracts against $\mathrm{CCl}_{4^{-}}$ induced liver injury in rats. J. Pharmacol. Toxicol. 1: 101- 107.

Iwu, M. M, Igboko, O. A, Onwuchekwa, U, Okunji, C. O. (1987). Evaluation of the antihepatotoxicity of the biflavanoids of Garcinia kola seeds. $J$. Ethnopharmacol. 21: 127-142.

Jollow, D. J., Thorgeirsson, S. S., Potter, W. Z., Hashimoto, M. and Mitchell, J. R. (1974). Acetaminophen induced hepatic necrosis VI. Metabolic disposition of toxic and non-toxic doses of acetaminophen. Pharmacology. 12: 251271.

Moore, M., Thor, H., Moore, G., Nelson, S., Moldeus, P. and Orrenius, S. (1985). The toxicity of acetaminophen and $\mathrm{N}$-acetyl P-benzoquinoneimine in isolated hepatocytes is associated with thio depletion and increased cystosolic $\mathrm{Ca} 2+. J$. Biol. Chem. 260: 13035-13040.

OECD (2001). OECD Guideline 425: Acute Oral Toxicity-Up-and-Down Procedure. In: OECD Guidelines for the Testing of Chemicals Vol.2 Organization for Economic Cooperation and Development. Paris, France.

Rabo, J. S. (1998). Toxicity studies and Trypanosuppressive effect of stem- back extract of Buturospermum and paradoxin, in Laboratory animals. Ph.D. Thesis, Department of Veterinary Pathology University of Maiduguri, pp: 15-50. 
Ringler, D.H. and L. Dabich, 1979. Hematology and Clinical Biochemistry. In: The Laboratory Rat. Vol.1, Baker, H.J., J.R. Lindsey and S. H. Weisbroth (Eds.) Academic Press. London. pp:105-118

Singh, I. (1980). In: Textbook of Biochemistry and Human Biology. Talwar, G. P. (ed.), Prentice Hall of India, New Delhi. pp. 201-203

Savides, M. C. and Oehme, F. W. (1983). Acetaminophen and its toxicity. J. Appl. Toxicol. 3: 95-111.

U.S.EPA, 2006: International classification schemes for environmental effects. Available at; http:/www.nicnas.gov.au/About_NICNAS/

Reforms/ LRCC/ Discussion_paper1
_A_3_PDF.pdf / Accessed: December 2008.
Vermeulen, N. P. E., Bessems, J. G. M. and Van de Streat, R (1992). Molecular aspects of paracetamol-induced hepatotoxicity and it mechanism based prevention. Drug Metab. Rev. 24: 367-407.

Wong, L. T., Whitehouse, L. W., Solemonraj, G. and Paul, C. J. (1981). Pathways of acetaminophen conjugate in the mouse. Toxicity Lett; 9: 145-151.

WHO (1992). World Health Organizations Quality control methods for medicinal plant materials. Geneva, Pp. 58 - 63.

Wittwer, F. M. and Bohmwald, L. H. (1986). Manuel de Patologia Clinica Veterinaria. Valdivia Chile, pp; 53-93.

Yoshinkuyi, M., Toshikaru, H. and Shogi, A. (1992). High Molecular protein aggregates formed in liver of rats. J. Pharm. Pharmacol. 44: 932 - 934. 